\title{
Plasmin enzymatic activity in the presence of actin
}

\author{
E. I. Yusova \\ Palladin Institute of Biochemistry, NAS of Ukraine \\ 9, Leontovycha Str., Kyiv, Ukraine, 01601 \\ yusova07@mail.ru
}

\begin{abstract}
Aim. To study the changes in the plasmin activity towards substrates with high and low molecular mass in the presence of actin. Methods. The proteins used for this investigation were obtained by affinity chromatography and gel-filtration. The plasmin enzymatic activity was determined by a turbidimetric assay and a chromogenic substrate-based assay. The enzyme linked immunosorbent assay and biotin-avidin-phosphatase system were used to study the interaction of plasminogen and its fragments with actin. Results. It was shown that G-actin caused 1.5-fold decrease in the rate of polymeric fibrin hydrolysis by plasmin and Glu-plasminogen activated by the tissue plasminogen activator. However, actin did not impede plasmin autolysis and had no influence on its amidase activity. We have studied an interaction of biotinylated Glu-plasminogen and its fragments (kringle 1-3, kringle 4 and mini-plasminogen) with immobilized G-actin. Glu-plasminogen and kringle 4 had a high affinity towards actin $\left(\mathrm{C}_{50}\right.$ is 113 and $117 \mathrm{nM}$ correspondingly). Mini-plasminogen and kringe 4 did not bind to actin. A similar affinity of Glu-plasminogen and kringle 1-3 towards actin proves the involvement of the kringle 1-3 lysine-binding sites of the native plasminogen form in the actin interaction. Conclusions. Actin can modulate plasmin specificity towards high molecular mass substrates through its interaction with lysine-binding sites of the enzyme kringle domains. Actin inhibition of the fibrinolytic activity of plasmin is due to its competition with fibrin for thelysine binding sites of plasminogen/plasmin.
\end{abstract}

Ke y w o r d s: Plasmin, actin, plasminogen fragments, enzymatic activity of plasmin.

\section{Introduction}

Plasminogen/plasmin system takes part in a wide spectrum of physiological and pathophysiological processes in human organism, such as reproduction, embryogenesis, tissue remodeling, allergic and inflammatory reactions, carcinogenesis and metastasis formation. The main role of this proteolytic system is fibrinolysis that prevents the formation of fibrin deposits or provides the degradation of the formed blood clots. A key reaction of the fibrinolytic process is the conversion of plasminogen (zymogen) to the active serine protease plasmin (E.C.3.21.7). Human plasma plasmin hydrolyzes fibrinogen, fibrin, coagulation factors V, VIII, XII, converts single chain forms of the tissue plasminogen activator (tPA) and urokinase to more active double-chained forms, activates metalloproteases and lipoxygenases, growth factors [1]. Multifunctional properties of plasmin are realized due to its high specificity towards different high molecular weight substrates, and, on the other hand, due to the changing of its specificity during the interaction with modulator proteins, cellular receptors. Specific binding of modulator proteins to plasmin influences its functional activity. One of the most studied regulators of the plasmin substrate specificity is streptokinase, a plasminogen activator of bacterial origin. Plasmin in a complex with streptokinase (unlike free protease) is able to activate plasminogen by cleavage of the Arg561-Val562 activation peptide bond in its molecule. Streptokinase increases the amidase activity of plasmin and de-

(C) 2015 E. I. Yusova; Published by the Institute of Molecular Biology and Genetics, NAS of Ukraine on behalf of Biopolymers and Cell.

This is an Open Access article distributed under the terms of the Creative Commons Attribution License (http://creativecommons.org/licenses/by/4.0/), which permits unrestricted reuse, distribution, and reproduction in any medium, provided the original work is properly cited 
creases its protease activity towards fibrin, its physiological substrate. The complex streptokinase-plasmin makes plasmin resistant to $\alpha_{2}$-antiplasmin, its physiological inhibitor [2-5].

Wang $\mathrm{H}$ et al. showed [6] that an extracellular membrane of the carcinoma PC-3,_HT 1080 and MDA-MB231 cellular lines contains $\beta$-actin that mediates both the plasmin interaction with cellular surface and the enzyme autoproteolysis leading to the formation of angiostatins 4.5. The similar effect of $\beta$-actin was observed in vitro in the cell-free system. Actin has been found in plasma of healthy subjects, and under different diseases associated with various types of the tissue and cell injury its concentration in the blood achieves a few micromoles. That is why the damaged cells are considered as the main source of circulating actin [7]. The actin concentration may be significantly increased due to the cell damage in the micro medium of the inflammation and clot formation sites, i.e. in the places where plasmin is localized and expresses its functional activity. To clarify the actin ability to modulate the specificity of action of free circulating plasmin, in the present work the actin influence on the changes in the plasmin activity towards substrates with high and low molecular mass was investigated.

\section{Materials and Methods}

Glu-plasminogen was purified from fresh citrated human plasma by affinity chromatography on lysineSepharose at $4{ }^{\circ} \mathrm{C}$ in the presence of aprotinin [8].

Mini-plasminogen (Val442-plasminogen) and plasminogen kringles K1-3 and K4 were obtained according to [9] by elastase hydrolyses of plasminogen.

Plasmin was obtained by activation of plasminogen on urokinase-Sepharose ( $1 \mathrm{mg}$ of zymogen/1250 IU urokinase) at $25^{\circ} \mathrm{C}$ in the presence of $25 \%$ glycerol. The enzyme was stored in the presence of $50 \%$ glycerol at $-20^{\circ} \mathrm{C}$.

Monomeric desAB-fibrin was obtained by dissolving thrombin fibrin clot formed in the presence of 100 $\mathrm{mM} \varepsilon$-aminocaproic acid ( $\varepsilon$-ACA) and inhibitor of factor XIIIa - parahydroxy mercury benzoate $(0.35 \mathrm{mg} /$ $\mathrm{ml}$ ) in $20 \mathrm{mM}$ acetic acid as described elsewhere [10].
For the estimation of fibrinolytic activity of plasmin or plasminogen activated by tissue activator, the turbidimetric method was applied as described in [11]. The final concentration of desAB-fibrin was $6.2 \cdot 10^{-7} \mathrm{M}$, plasmin $-3.5 \cdot 10^{-8} \mathrm{M}$, Glu-plasminogen $-3.2 \cdot 10^{-8} \mathrm{M}$, tissue activator $-100 \mathrm{IU}$, actin $-35 \cdot 10^{-8} \mathrm{M}$ or $32 \cdot 10^{-8} \mathrm{M}$. The rate of fibrin clot lysis by plasmin was calculated as $\mathrm{V}=1 / \mathrm{t}_{1 / 2}$. Time $\mathrm{t}_{1 / 2}$ was measured as the time period from the initiation step of the clot formation till the step characterized by $50 \%$ fall in absorbance from maximum. To study the effects of actin on the rate of plasmin-mediated fibrin clot lysis, $35 \cdot 10^{-8} \mathrm{M}$ or $32 \cdot 10^{-8} \mathrm{M}$ actin was added to the reaction medium.

The amidase activity of plasmin in the presence of actin was estimated by measuring p-nitroaniline release by plasmin from specific chromogenic substrate S2251 (H-D-Val-L-Leu-L-Lys-p-nitroanilide). Study was performed in 96-well microtiter plates (Greiner bio-one, Germany) in $0.05 \mathrm{M}$ tris-HCl buffer with $0.13 \mathrm{M} \mathrm{NaCl}, \mathrm{pH} 7.4$ at $37^{\circ} \mathrm{C}$ with following concentration of components of the mixture: plas$\min -2 \cdot 10^{-9} \mathrm{M}$, actin $-2 \cdot 10^{-9} \mathrm{M}$ or $20 \cdot 10^{-9} \mathrm{M}$, $\mathrm{S} 2251-3 \cdot 10^{-3} \mathrm{M}$. Total volume of the mixture was $0.25 \mathrm{ml}$. The absorbance of p-nitroaniline was continuously monitored at 405-492 nm using microplate reader (Titertek Multiskan MC, Finland).

To detect the plasmin autolysis in the presence or in the absence of actine the amidolytic activity of enzyme preincubated during different time was studied. Plasmin $\left(1 \cdot 10^{-6} \mathrm{M}\right)$ was incubated in $0.6 \mathrm{ml} 0.05$ $\mathrm{M}$ tris-HCl buffer with $0.13 \mathrm{M} \mathrm{NaCl}(\mathrm{pH} 7.4)$ with/ without actine $\left(1 \cdot 10^{-5} \mathrm{M}\right) .0 .05 \mathrm{M}$ tris- $\mathrm{HCl}$ buffer with $0.13 \mathrm{M} \mathrm{NaCl}, \mathrm{pH} 7.4$, plasmin $-3.5 \cdot 10^{-8} \mathrm{M}$, actin $-35 \cdot 10^{-8} \mathrm{M}, \mathrm{S} 2251-3 \cdot 10^{-3} \mathrm{M}$ were added to the thermostatic cuvette of SF 26 . Total volume of the mixture was $1 \mathrm{ml}$. The absorbance of p-nitroaniline was monitored at certain time intervals at $405 \mathrm{~nm}$. The amount of hydrolysed substrate was calculated using following formula:

$$
\mathrm{V}=\Delta \mathrm{A}_{405} / \Delta \mathrm{t}
$$

where $\Delta \mathrm{A}_{405}$ is a change of absorbance at $405 \mathrm{~nm}$ and $\Delta \mathrm{t}$ is a time of absorbance measuring.

Biotinylation of Glu-plasminogen and its fragments was carried out as described in [12]. 
Binding assay was performed using avidin-biotin system. Biotin labeling of Glu-plasminogen and tPA was carried out according to manufacturer recommendation. The wells of high binding polysterene microtitrate plates (Nunc, MaxiSorp) were coated with $1 \mu \mathrm{g}$ of actin in $0.1 \mathrm{ml} 0.01 \mathrm{M}$ sodium phosphate buffer ( $\mathrm{pH} 7.4$ ) and $0.15 \mathrm{M} \mathrm{NaCl}$ at $4^{\circ} \mathrm{C}$ overnight. After binding an excess of protein were removed by washing buffer with $0.1 \%$ Tween 20 . To avoid nonspecific sorption, $2 \%$ BSA was pipetted into the plate wells, incubated for $2 \mathrm{~h}$ at $37^{\circ} \mathrm{C}$ and washed out. After washing procedures, bound actin in each well was incubated with $0.1 \mathrm{ml}$ biotinylated Glu-plasminogen or its fragments for $4 \mathrm{~h}$ at $37^{\circ} \mathrm{C}$ and washed out. Then 0.1 $\mathrm{ml}$ of avidin-phosphatase solved, as manufacturer recommends, were added into the wells and washed out after 60 min incubation. $0.1 \mathrm{ml}$ of alkaline phosphatase substrate $(1 \mathrm{mg} / \mathrm{ml} \mathrm{p}$-nitrophenylphosphate in 10 $\%$ diethanolamine, $\mathrm{pH} 9.8$ ) was pipetted in the wells and incubated for $45 \mathrm{~min}$ at $37^{\circ} \mathrm{C}$. The binding of biotin labeled proteins with actin immobilized on the well surface was estimated by measurement of p-nitrophenol absorbance at $405 \mathrm{~nm}$ using the reader (Titertek Multiscan, Finland).

The protein concentration was determined as the difference between the solution optical density at $280 \mathrm{~nm}$ and $320 \mathrm{~nm}$. To calculate the protein concentration we used the following values of the extinction coefficient $\left(\mathrm{E}_{280}, 1 \%, 1 \mathrm{~cm}\right)$ and molecular mass respectively: Glu-plasminogen -17.0 and $92 \mathrm{kDa}$, plasmin - 17.0 and $84 \mathrm{kDa}$ [13], mini-plasminogen 14.0 and $38 \mathrm{kDa}$ [9], des $\mathrm{AB}$ fibrin-monomer- 15.06 and $300 \mathrm{kDa}[10]$.

The obtained proteins were homogeneous according to the electrophoresis data in PAAG [14].

The data $\mathrm{w}$ analysed by ORIGIN 8.6 (Originlab Corporation, USA). The permissible error did not exceed $5 \%(\mathrm{P}<0.05)$. The presented curves are typical for a set of repeated experiments (at least three repeats for each experiment).

\section{Results and Discussion}

In circulating blood plasminogen, zymogen of plasmin, is present as a Glu-form, a glycoprotein composed of 791 amino acids. The conversion of plasminogen in plasmin is the key process of fibrinolysis. The plasminogen activation by physiological activators, such as tPA, urokinase, is mainly based on the enzymatic cleavage of a single peptide bond Arg561-Val562 $[15,16]$. The cleavage results in the formation of the enzyme active center as well as in the appearance of a two-chain plasmin molecule, composed of an N-terminal heavy-chain (A) with molecular mass of $56 \mathrm{kDa}$ and a $\mathrm{C}$-terminal light one (B) with molecular mass of $26 \mathrm{kDa}$. The light chain has two disulfide bonds Cys 548-Cys 666 and Cys 558-Cys 566. The desAB fibrin is known as a potent stimulator of the activation reaction [17]. In solutions in the absence of fibrin, Glu-plasminogen (a native form of zymogen) is activated very slowly by $\mathrm{t}-\mathrm{PA}$. The reaction is characterized by a low value of $\mathrm{k}_{\text {cat }}\left(0.06 \mathrm{~s}^{-1}\right)$, and $\mathrm{Km}$ is approximately $60 \mu \mathrm{M}$. In the presence of fibrin, $\mathrm{Km}$ decreases till $0.16 \mu \mathrm{M}$, and $\mathrm{k}_{\text {cat }}$ value increases till $0.1 \mathrm{~s}^{-1}$. Besides fibrin, the tPA-dependent plasmin formation can be stimulated by the products of fibrin(ogen) hydrolysis, membrane-bound proteins, intercellular matrix proteins such as thrombospondin, gelatin, and collagen IV [18].

Nowadays, there are many data confirming physiological importance of the plasmin(ogen) interaction with actin. They considered the regulation activity of fibrinolytic system and the processing of biologically active molecules as well as the modulating action of plasminogen/plasmin system on the cells [19]. It was established that actin has a high affinity towards plasmin and tPA $\left(\mathrm{K}_{\mathrm{d}} 70-140 \mathrm{nM}\right.$ and $0.55 \mu \mathrm{M}$, correspondingly) [20]. The actin influence on the rate of fibrin clot degradation by the free enzyme and by plasmin formed due to the Glu-plasminogen activation by tPA was studied with G-actin (the protein monomeric soluble form) using turbidimetric assay. As it is shown in Fig.1, actin inhibits both the plasmin activity and the enzyme formed as a result of the Glu-plasminogen activation by tPA. At 10 fold molar excess of actin, the rate of hydrolysis of polymeric desAB fibrin reduced by approximately $50 \%$ in both cases. 


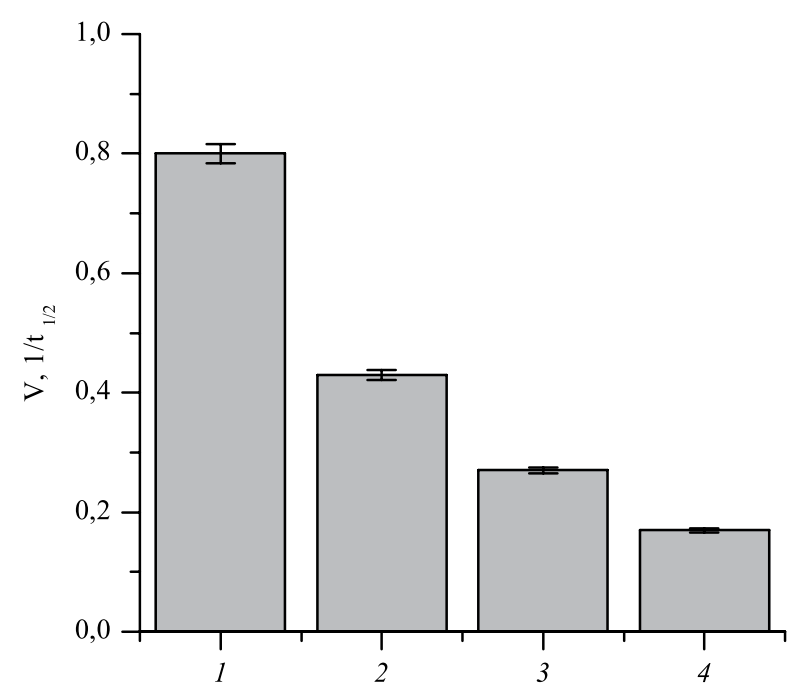

Fig. 1. Rates of desAB fibrin clots lysis by plasmin (1), plasmin in the presence of actin (2), Glu-plasminogen activated by tissue activator (3), Glu-plasminogen activated by tissue activator in the presence of actin (4)

The observed effect of actin can be a result of the protein interaction with the enzyme active center or with the lysine-binding sites of plasmin(ogen) kringle domains, that are responsible for the plasmin interaction with its physiological substrate, polymeric

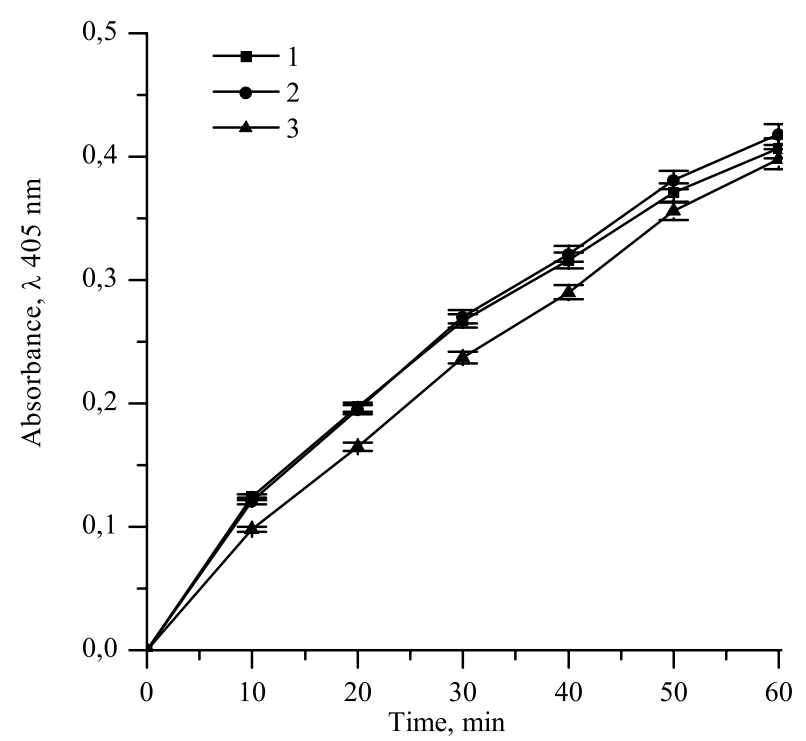

Fig. 2. Influence of actin on the plasmin amidase activity: 1 plasmin $\left(2 \cdot 10^{-9} \mathrm{M}\right) ; 2-$ plasmin $\left(2 \cdot 10^{-9} \mathrm{M}\right)$ with actin $\left(2 \cdot 10^{-9} \mathrm{M}\right)$; 3 - plasmin $\left(2 \cdot 10^{-9} \mathrm{M}\right)$ with actin $\left(20 \cdot 10^{-9} \mathrm{M}\right)$ fibrin. To clarify this problem we investigated the amidase activity and enzyme autolysis in the presence of actin. It was shown that actin taken in equimolar amount or in 10 fold molar excess makes no influence on the plasmin amidase activity. The rate of hydrolysis of plasmin chromogenic substrate in the absence and in the presence of actin does not change during 60 minutes and is within 0.0068 optical units per minute. (Fig. 2).

To determine the possible influence of actin on the enzyme autolysis, we incubated plasmin or plasmin mixture with two-molar excess of actin for $3 \mathrm{~h}$ at $37^{\circ} \mathrm{C}$. The aliquots of reaction mixture were taken at certain intervals and added to the medium to determine the amidase activity. The presented data (see Fig. 3) do not show any effect of actin. A decrease in the enzyme amidolytical activity was observed when the enzyme was preincubated in the absence or in the presence of actin. After three-hour incubation, the residual amidase activity was approximately $30 \%$ of the original in both cases (Fig. 3).

According to the presented results we can conclude that during the actin interaction with plasmin, the plasmin active center is open and available for

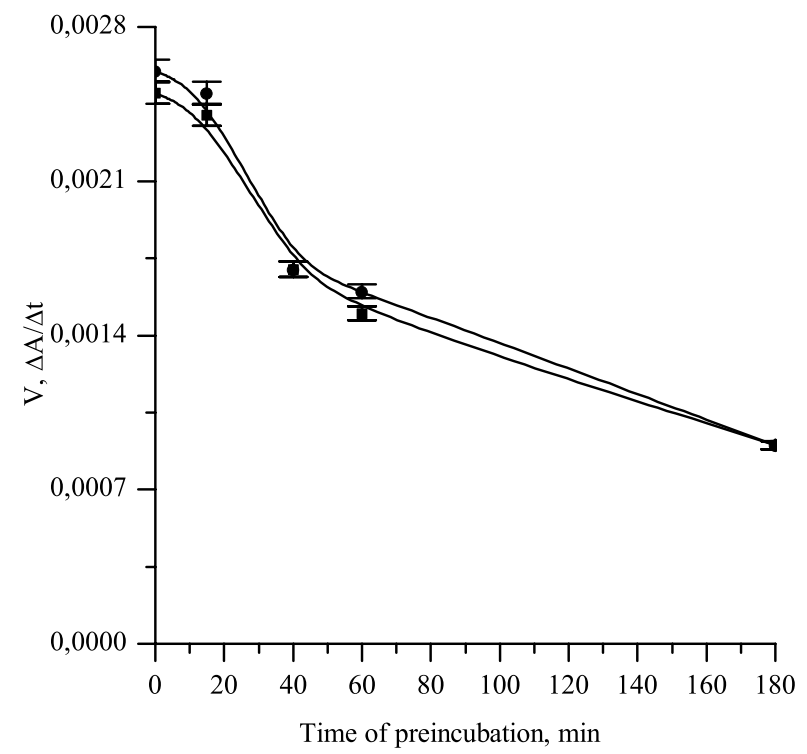

Fig. 3. Dependence of the rate of S2251 hydrolysis by plasmin (1); plasmin in the presence of actin (1:10) on the enzyme preincubation time 
Table I. Binding of biotinylated Glu-plasminogen and its fragments with immobilized actin

\begin{tabular}{|l|c|}
\hline Proteins & $\mathrm{C}_{50}, \mathrm{nM}$ \\
Glu-plasminogen & 113 \\
Kringl[e] 1-3 & 117 \\
Kringl[e] 4 & - \\
Mini-plasminogen & - \\
\hline
\end{tabular}

the substrates with high and low molecular mass. Actin inhibition of the plasmin fibrinolytic activity is probably due to the actin interaction with lysinebinding sites of enzyme kringle domains. To prove this suggestion we compared actin binding to Gluplasminogen and its fragments: first three kringles (K1-3), fourth kringle (K4) and Val442-plasminogen (mini-plasminogen). The investigations were carried out using linked immunosorbent assay and a biotinavidin phosphatase system. Actin was deposited onto the surface of microtiter plate wells. Then, prebiotinylated plasminogen and its fragments (1-50 $\mu \mathrm{g} / \mathrm{ml})$ were added to wells. After that phosphataselabeled avidin was added. Adsorption of the proteins was measured according to the amount of $p$-nitrophenylphosphate converted by the phosphatase. The protein concentrations corresponding to $50 \%$ saturation of binding sites for actin were determined using the obtained saturation curves. As it is shown in Table 1, actin has equally high affinity towards the native zymogen molecule and its fragment $\mathrm{K}$ 1-3. $\mathrm{C}_{50}$ values are 113 and $117 \mathrm{nM}$, correspondingly. At the same time, there is no binding of actin to isolated kringle 4 or mini-plasminogen. Similar affinity of Glu-plasminogen and kringle 1-3 to actin gives us the reason to believe that lysine-binding sites of first three kringle domains of the proenzyme are involved into interaction with actin.

So, we have shown that actin can modulate specificity of the plasmin action towards substrates with high molecular mass through its interaction with lysine-binding sites of enzyme kringle domains. The actin inhibition of the fibrinolytic activity of plasmin is due to its competition with fibrin for lysine binding sites of plasminogen/plasmin. Thus, actin can cause a reduction of fibrinolytic system potential and can be involved in the hemostasis disorders related to sepsis, inflammation and tissue damages.

\section{REFERENCES}

1. Syrovets T, Lunov O, Simmet T. Plasmin as a proinflammatory cell activator. J Leukoc Biol. 2012;92(3):509-19.

2. Marcum JA, Kline DL. Species specificity of streptokinase. Comp Biochem Physiol B. 1983;75(3):389-94.

3. Wohl RC, Sinio L, Summaria L, Robbins KC. Comparative activation kinetics of mammalian plasminogens. Biochim Biophys Acta. 1983;745(1):20-31.

4. Castellino FJ, Sodetz JM, Brockway WJ, Siefring GE Jr. Streptokinase. Methods Enzymol. 1976;45:244-57.

5. Cederholm-Williams SA, De Cock F, Lijnen HR, Collen D. Kinetics of the reactions between streptokinase, plasmin and alpha 2-antiplasmin. Eur J Biochem. 1979;100(1):125-32.

6. Wang H, Schultz R, Hong J, Cundiff DL, Jiang K, Soff GA. Cell surface-dependent generation of angiostatin4.5. Cancer Res. 2004;64(1):162-8.

7. Mejean C, Roustan C, Benyamin Y. Anti-actin antibodies. Detection and quantitation of total and skeletal muscle actin in human plasma using a competitive ELISA. J Immunol Methods. 1987;99(1):129-35.

8. Deutsch DG, Mertz ET. Plasminogen: purification from human plasma by affinity chromatography. Science. 1970;170(3962):1095-6.

9. Sottrup-Jensen L, Claeys H, Zajdel M, Petersen TE, Magnusson $S$. The primary structure of human plasminogen: isolation of two lysine-binding fragment and one "miniplasminogen" (M.W. 38000) by elastase catalyzed specific limited proteolysis In: Progress in chemical fibrinolysis and thrombolysis. Eds VF Davidson, Rowan RH, Samama MM, Desnoyers DC. Raven Press, New-York. 1977;3:191-9,

10. Pozdnjakova TM, Musjalkovskaja AA, Ugarova TP, Protvin DD, Kotsjuruba $V N$. On the properties of fibrin monomer prepared from fibrin clot with acetic acid. Thromb Res. 1979;16(1-2):283-8.

11. Bouvier SA, Beretta-Piccoli M, Giacometti N. Light scattering measurements of polymerization and depolimerization of fibrin: a tool for studing coagulation and fibrinolysis. Progress in chemical fibrinolysis and thrombolysis. Eds. Davidson JF et al. N.Y.:Raven Press 1975;1:281-88.

12. Gitlin $G$, Bayer EA, Wilchek $M$. Studies on the biotin-binding site of avidin. Lysine residues involved in the active site. Biochem J. 1987;242(3):923-6.

13. Violand BN, Castellino FJ. Mechanism of the urokinasecatalyzed activation of human plasminogen. J Biol Chem. 1976;251(13):3906-12.

14. Laemmli UK. Cleavage of structural proteins during the assembly of the head of bacteriophage T4. Nature. 1970;227(5259):680-5.

15. Robbins KC, Summaria L, Hsieh B, Shah RJ. The peptide chains of human plasmin. Mechanism of activation of human plasminogen to plasmin. $J$ Biol Chem. 1967;242(10):2333-42. 
16. Hoylaerts $M$, Rijken DC, Lijnen HR, Collen D. Kinetics of the activation of plasminogen by human tissue plasminogen activator. Role of fibrin. J Biol Chem. 1982;257(6):2912-9.

17. Stack S, Gonzalez-Gronow M, Pizzo SV. Regulation of plasminogen activation by components of the extracellular matrix. Biochemistry. 1990;29(20):4966-70.

18. Zhernossekov DD, Yusova EI, Grinenko TV. Role of plasminogen/plasmin in functional activity of blood cells. $U k r$ Biokhim Zh. 2012;84(4):5-19

19. Tykhomyrov $A A$. Interaction of actin with plasminogen/plasmin system: mechanisms and physiological role. Biopolym Cell. 2012; 28(6):413-23.

20. Lind SE, Smith CJ. Actin accelerates plasmin generation by tissue plasminogen activator. J Biol Chem. 1991;266(26):17673-8.

\section{Ензиматична активність плазміну в присутності актину}

\section{О. І. Юсова}

Мета. Дослідити зміну активності плазміну по відношенню до високо- та низькомолекулярних субстратів за присутності актину. Методи. Протеїни, які використовувались в роботі, отримували афінною хроматографією, гель-фільтрацією та електрофорезом. Ензиматичну активність плазміну досліджували турбідіметрією та методом визначення активності з використанням хромогенного субстрату. Для вивчення взаємодії між плазміногеном та його фрагментами і актином використовували принцип імуноферментного аналізу та авідин-біотинову реакцію. Результати. Показано, що G-актин знижує в 1,5 рази швидкість гідролізу полімерного фібрину плазміном i Glu-плазміногеном, активованим тканинним активатором. Разом з тим, актин не запобігає автолізу плазміну і не впливає на його амідазну активність. Досліджено взаємодію біотинільованих Glu-плазміногену та його фрагментів - кринглу1-3, кринглу 4 та міні-плазміногену з імобілізованим G-актином. Показано, що Glu-плазміноген i крингл 1-3 виявляють високу спорідненість до актину $\left(\mathrm{C}_{50} 113\right.$ і 117 нМ відповідно). Міні-плазміноген та крингл 4 з актином не зв'язуються. Однакова спорідненість Glu-плазміногену і крингла 1-3 до актину свідчать про участь лізин-зв'язувальних ділянок крингла 1-3 нативної форми плазміногену у взаємодії з актином. Висновки. Актин може модулювати специфічність дії плазміну по відношенню до високомолекулярних субстратів шляхом його взаємодії з лізин-зв'язувальними ділянками кринглових доменів ензима. Пригнічення актином фібринолітичної активності плазміна обумовлене його конкуренцією з фібрином за лізин-зв'язувальні сайти плазміногену/плазміну.

К л юч о в і с л о в а: плазмін, актин, фрагменти плазміногену, ензиматична активність плазміну.

\section{Энзиматическая активность плазмина в присутствии актина}

Е. И. Юсова

Цель. Исследовать изменение активности плазмина по отношению к высоко- и низкомолекулярным субстратам в присутствии актина. Методы. Протеины, использованные в работе, получали аффинной хроматографией, гель фильтрацией и элетрофорезом. Энзиматическую активность плазмина исследовали турбидиметрией и методом определения активности по хромогенному субстрату. Для изучения взаимодействия плазминогена и его фрагментов с актином использовали принцип иммуноферментного анализа и авидин-биотиновую реакцию. Результаты. Показано, что G-актин снижает в 1,5 раз скорость гидролиза полимерного фибрина плазмином и Gluплазминогеном, активированным тканевым активатором. Вместе с тем, актин не препятствует автолизу плазмина и не влияет на его амидазную активность. Исследовано взаимодействие биотинилированных Glu-плазминогена и его фрагментов: крингла 1-3, крингла 4 мини-плазминогена с иммобилизованным G-актином. Glu-плазминоген и крингл 1-3 проявляют высокое сродство к актину $\left(\mathrm{C}_{50} 113\right.$ и 117 нМ соответственно). Мини-плазминоген и крингл 4 с актином не связываются. Одинаковая аффинность Glu-плазминогена и крингла 1-3 к актину свидетельствует об участии лизинсвязывающих сайтов крингла 1-3 нативной формы плазминогена во взаимодействии с актином. Выводы. Актин может моделировать специфичность действия плазмина по отношению к высокомолекулярным субстратам благодаря его взаимодействию с лизинсвязывающими участками крингловых доменов энзима. Угнетение актином фибринолитической активности плазмина обусловлено его конкуренцией с фибрином за лизинсвязывающие сайты плазминогена/плазмина.

Кл ю ч е в ы е с л о в а: плазмин, актин, фрагменты плазминогена, энзиматическая активность плазмина

Received 03.07.2015 